\title{
Analisis Perbandingan Kinerja Badan Penanaman Modal serta Pengaruh PMA dan PMDN terhadap Pertumbuhan Ekonomi di Indonesia
}

\author{
Fajri Ardiansyah $^{1}$, Suhairi $^{2}$, Nini Syofri Yeni ${ }^{3}$ \\ 1,2,3Pasca Sarjana Akuntansi, Fakultas Ekonomi, Universitas Andalas, Indonesia \\ *Correspondence e-mail: fajriardiansyah1202@gmail.com
}

\begin{abstract}
Abstrak. Penelitian ini bertujuan untuk mengetahui perbandingan kinerja Badan Penanaman Modal daerah di Indonesia dan menguji pengaruh PMA dan PMDN terhadap pertumbuhan ekonomi. Sampel yang digunakan dalam penelitian ini adalah 34 BPMPTSP di seluruh Provinsi di Indonesia selama tahun 2015-2018 menggunakan metode purposive sampling. Data yang digunakan adalah data sekunder berupa target dan realisasi penanaman modal asing dan dalam negeri dari BKPM serta data PDRB dari BPS. Teknik analisis data yang digunakan adalah rata-rata jumlah realisasi penanaman modal setiap daerah, pertumbuhan rata-rata penanaman modal (Rasio CAGR), dan rata-rata rasio capaian target penanaman modal (Rasio efektivitas). Untuk menguji pengaruh investasi terhadap pertumbuhan ekonomi menggunakan regresi data panel. Hasil analisis rata-rata jumlah realisasi penanaman modal asing menunjukan bahwa Provinsi Jawa Barat merupakan daerah dengan kinerja terbaik, sedangkan untuk rata-rata jumlah realisasi penanaman modal dalam negeri, Provinsi Jawa Timur adalah daerah dengan kinerja terbaik. Provinsi Sulawesi Barat adalah daerah dengan kinerja terbaik ditinjau dari pertumbuhan rata-rata penanaman modal asing, sedangkan Provinsi Maluku daerah dengan kinerja terbaik ditinjau dari pertumbuhan rata-rata penanaman modal dalam negeri. Berdasarkan rata-rata rasio capaian target penanaman modal, Sulawesi Utara adalah daerah dengan kinerja terbaik. Hasil Uji F menunjukan bahwa secara simultan terdapat pengaruh penanaman modal asing dan dalam negeri secara simultan terhadap pertumbuhan ekonomi. Hasil Uji t menunjukan bahwa secara parsial penanaman modal asing dan dalam negeri berpengaruh signifikan terhadap pertumbuhan ekonomi.
\end{abstract}

Kata kunci: Badan Penanaman Modal; Kinerja; Penanaman Modal Asing; Penanaman Modal dalam Negeri dan Pertumbuhan Ekonomi.

Abstract. This research aimed to know comparative Regional Board of Investment Performance in Indonesia and examined effect of foreign and domestic investment on economic growth. Sample used in this research is 34 Board of Investment and Integrated Licensing (BPMPTSP) of the provinces in Indonesia in 2015-2018 that determined by purposive sampling method. Data used is secondary data of target and realization of foreign and domestic investment from BKPM and PDRB rate from BPS. Data analysis technique used is average of total realization of investment, average growth per year of investment (CAGR ratio), average ratio of investment target achievement (Effectiveness ratio). To examined effect of investment on economic growth used data panel regression analysis. Result of average of total realization of investment analysis show that West Java Province has best performance on foreign investment, while East Java as the best province on average realization of direct investment. West Sulawesi Province has the best performance measured by average growth of foreign investment, while Maluku is a province with best performance based on ratio of average growth of domestic investment. Analysis of target achievement that used effectiveness ratio show that North Sulawesi has the best performance on achieved the investment target. F- test result show that simultaneously there are significant effect between foreign and domestic investment on economic growth. Based on t-test result, partially there are significant effect between foreign and domestic investment on economic growth.

Keywords: Board of Investment; Domestic Investment; Economic Growth; Foreign Investment and Performance.

\section{PENDAHULUAN}

Pertumbuhan ekonomi yang terus meningkat dan berkesinambungan, merupakan tekad yang ingin diwujudkan oleh Pemerintah Indonesia. Terbatasnya dana yang dimiliki pemerintah untuk menggerakkan pertumbuhan ekonomi maka peran investasi baik dari luar negeri (PMA) maupun dari dalam negeri (PMDN) sangat diharapkan (Ambarsari dan Purnomo, 2005). Oleh karena itu investasi menjadi isu yang sangat penting pada pemerintahan saat ini sejak Presiden Joko Widodo dilantik menjadi Presiden Indonesia. Salah satu bentuk keseriusan pemerintah untuk mendorong kemajuan ekonomi khusunya peningkatan investasi, pemerintah mengeluarkan beberapa paket kebijakan ekonomi berupa penyederhanaan peraturan (deregulasi) dan penyederhanaan birokrasi (debirokratisasi) untuk mempermudah investasi.

Selain mengeluarkan berbagai kebijakan ekonomi, pemerintah juga melakukan peyederhanaan birokrasi dengan membentuk Lembaga/ Badan/ Dinas Pelayanan Satu Pintu sesuai dengan Peraturan Presiden Nomor 97 tahun 2014 tentang Penyelenggaran Pelayanan Satu Pintu. Pemerintah pusat mendelegasikan kepada Badan Koordinasi Penanaman Modal (BKPM) untuk melakukan pelayanan perizinan atau non perizinan di bidang penanaman modal yang menjadi urusan pemerintah pusat, serta pemerintah daerah mendelegasikan wewenang perizinan dan non perizinan di daerah kepada Badan Penanaman Modal dan Pelayanan Terpada Satu Pintu (BPMPTSP). Sebagai 
pelimpahan wewenang dari BKPM, BPMPTSP memiliki sasaran dan indikator kinerja untuk meningkatkan realisasi penanaman modal di daerah.

Penggunaan akan pengukuran kinerja pada organisasi publik akan menentukan bagaimana kinerja organisasi tersebut (Sulle, 2014). Selain itu David et al (2001), berpendapat bahwa pengukuran kinerja saat ini menjadi barometer manajemen kinerja, sebab memberikan informasi kepada publik mengenai pekerjaan organisasi publik.

Firdaus dan Widyasastrena (2016), melakukan penelitian untuk menilai minat dan realisasi investasi di Provinsi Jawa Barat. Penelitian ini dilakukan untuk mengukur kinerja pada Badan Penanaman Modal dan Pelayanan Terpadu (BPMPT) Jawa Barat. Diperoleh hasil bahwa terjadi peningkatan minat investasi pada Kabupaten dan Kota di Provinsi Jawa Barat baik itu PMA maupun Penanaman Modal dalam Negeri PMDN.

Menurut Todaro (2003), salah satu faktor utama dalam pertumbuhan ekonomi adalah akumulasi modal yang berhubungan dengan investasi dalam memupuk stok modal untuk menghasilkan pendapatan di masa yang akan datang. Khairunnisa, Sulistyo dan Kusuma (2018), melakukan penelitian untuk mengukur pengaruh penamanan modal asing dan penanaman modal dalam negeri serta pengeluaran pemerintah terhadap pertumbuhan ekonomi di Povinsi Kalimantan Selatan. Diperoleh hasil bahwa baik secara simultan dan parsial penanaman modal berpengaruh terhadap pertumbuhan ekonomi di daerah.

Penelitian ini bertujuan untuk menentukan provinsi manakah yang memiliki kinerja terbaik ditinjau dari rata-rata jumlah realisasi penanaman modal, ratarata pertumbuhan penanaman modal, rata-rata rasio capaian target penanaman modal dan menguji pengaruh investasi terhadap pertumbuhan ekonomi.

\section{Organisasi Sektor Publik}

Organisasi didefinisikan sebagai sekelompok orang yang berkumpul dan berkerjasama dengan cara yang terstruktur untuk mencapai tujuan atau sejumlah sasaran tertentu yang telah ditetapkan bersama-sama. Sedangkan sektor publik merupakan segala sesuatu yang berhubungan dengan kepentingan umum dan penyediaan barang dan jasa kepada publik yang dibayar melalui pajak atau pendapatan negara lainnya yang diatur dengan hukum (Mahsun, 2009). Menurut Jones (1993), sektor publik memiliki beberapa peran, yaitu:

1) Regulatory role, artinya sektor publik mempunyai peran dalam menetapkan segala aturan yang berkaitan dengan kepentingan umum;

2) Enabling role, sektor publik berperan untuk menjamin terlaksananya peraturan yang sudah ditetapkan dalam penyediaan barang dan jasa publik;

3) Direct provision of goods and services, disebabkan oleh semakin kompleksnya area yang harus di laksanakan oleh sektor publik dan adanya keterbatasan dalam pembiayaan barang dan jasa publik secara langsung sehingga pemerintah dapat melakukan privatisasi.

\section{Kinerja Organisasi Sektor Publik}

Menurut Mahsun (2009), kinerja merupakan gambaran mengenai tingkat pencapaian pelaksanaan suatu kegiatan/ program/ kebijakan dalam mewujudkan sasaran, tujuan, visi, dan misi organisasi yang tertuang dalam strategic planning suatu organisasi. Pengukuran kinerja adalah suatu proses penilaian kemajuan pekerjaan terhadap tujuan dan sasaran yang telah ditentukan sebelumnya, termasuk informasi atas: efisiensi penggunaan sumber daya, kualitas barang dan jasa dan hasil kegiatan dibandingkan dengan maksud yang diinginkan (Robertson, 2002).

Dalam rangka pengukuran tingkat keberhasilan organisasi sangat dibutuhkan adanya indikator kinerja yang jelas oleh stakeholders (Kristiyanti, 2012). Indikator kinerja adalah ukuran kuantitatif atau kualitatif yang menggambarkan seberapa besar pencapaian suatu sasaran atau tujuan yang telah ditetapkan suatu organisasi (Mahsun, 2009).

Adapun tahapan dalaam melakukan Pengukuran kinerja adalah (Mahsun, 2009): perencanaan strategi, penciptaan indikator kinerja, mengembangkan sistem pengukuran kinerja, penyempurnaan ukuran dan melakukan pengintegrasian dengan proses manajemen.

\section{Investasi}

Menurut SAP 06, investasi adalah aset yang dimaksudkan untuk memperoleh manfaat ekonomi seperti bunga, dividen dan royalti, dan/atau manfaat sosial, sehingga dapat meningkatkan kemampuan pemerintah dalam rangka pelayanan kepada masyarakat. Mankiw (2003) berpendapat bahwa investasi terdiri dari barang-barang yang di beli untuk penggunaan di masa depan.

\section{Penanaman Modal Asing (PMA)}

Berdasarkan Undang-Undang Republik Indonesia Nomor 25 Tahun 2007 dalam Pasal 1 Ayat 9 Tentang Penanaman Modal, PMA adalah kegiatan menanam modal untuk melakukan usaha di wilayah negara Republik Indonesia yang dilakukan oleh penanam modal asing, baik yang menggunakan modal asing sepenuhnya maupun yang berpatungan dengan penanam modal dalam negeri. Penanaman modal menjadi salah satu sumber dana untuk pembangunan bagi pemerintah selain menggunakan dana APBN/APBD.

\section{Penanaman Modal dalam Negeri (PMDN)}

Berdasarkan Undang-Undang No. 25 Tahun 2007 tentang Penanaman Modal Pasal 1 Ayat 2 menyebutkan bahwa Penanaman Modal Dalam Negeri adalah Kegiatan menanam modal untuk melakukan usaha di 
wilayah Negara Republik Indonesia yang dilakukan oleh penanam dalam negeri dengan menggunakan modal dalam negeri. Ditengah keterbatasan dana APBN/APBD, penanaman dalam negeri menjadi salah satu sumber dana yang dapat digunakan pemerintah untuk melakukan pembangunan di daerah sehingga dapat meningkatkan pertumbuhan ekonomi.

\section{Pertumbuhan Ekonomi}

Pertumbuhan ekonomi dapat diartikan sebagai perkembangan kegiatan dalam perekonomian yang menyebabkan barang dan jasa yang diproduksikan dalam masyarakat bertambah (Sukirno, 2002). Todaro dan Smith (2003) mengidentifikasikan bahwa terdapat tiga faktor utama dalam pertumbuhan ekonomi dari setiap bangsa, yaitu:

1) Akumulasi Modal, terjadi apabila sebagian dari pendapatan ditabung dan diinvestasikan kembali dengan maksud untuk memperbesar output dan pendapatan di kemudian hari;

2) Pertumbuhan penduduk dan angkatan kerja, Jumlah tenaga kerja yang lebih banyak berarti akan meningkatkan tenaga kerja produktif, sedangkan pertumbuhan penduduk yang lebih besar berarti meningkatkan ukuran pasar domestiknya;

3) Kemajuan Teknologi, terjadi karena ditemukan metode baru atau perbaikan atas metode lama dalam menangani pekerjaan-pekerjaan tradisional. Kemajuan teknologi ini akan menghasilkan metode produksi padat karya yang lebih baik dan efisien.

Menurut Sabir (2015), pertumbuhan ekonomi di suatu negara dapat direfleksikan dengan pendapatan domestik bruto (PDB). Sedangkan pertumbuhan ekonomi di daerah dapat kita lihat dari Produk Domestik Regional Bruto (PDRB). PDRB adalah produksi total atau output barang dan jasa dalam jangka waktu tertentu (satu tahun), yang dihasilkan oleh suatu daerah. Adanya kenaikan atau penurunan PDRB mengindikasikan bahwa terjadi kenaikan dan penurunan produksi barang dan jasa di suatu daerah. Maka dengan adanya kenaikan PDRB maka terjadi pula pertumbuhan ekonomi yang baik di suatu daerah.

\section{Hipotesis}

Todaro dan Smith (2003) salah satu komponen utama dalam pertumbuhan ekonomi adalah akumulasi modal, yaitu sebagian pendapatan yang diinvestasikan untuk menambah kapasitas produksi dimasa yang akan datang.Teori pertumbuhan ekonomi yang diutarakan oleh Harrod-Domar, menyatakan bahwa untuk menumbuhkan suatu perekonomian diperlukan pembentukan modal sebagai tambahan stok modal dan menambah kapasitas produksi dimasa akan datang.

Rahman, Soelistyo dan Hadi (2016) melakukan penelitian dengan menguji pengaruh investasi, pengeluaran pemerintah, dan penduduk yang bekerja terhadap PDRB di Banten dan memperoleh hasil bahwa penanaman modal asing berpengaruh terhadap pertumbuhan ekonomi. Penelitian ini sejalan dengan penelitian yang dilakukan oleh Rizky, Agustin dan Mukhlis (2016), yang melakukan penelitian untuk menguji pengaruh penanaman modal dan belanja modal terhadap pertumbuhan ekonomi di Indonesia. Hasil yang diperoleh yaitu, penanaman modal asing berpengaruh positif dan signifikan terhadap pertumbuhan ekonomi.

\section{$\mathbf{H}_{\mathbf{a}}=$ Penanaman Modal Asing berpengaruh terhadap pertumbuhan ekonomi}

Dalam teori Harrod Dumar (1939), salah satu faktor yang akan memajukan dan meningkatkan perekonomian adalah investasi salah satunya dalam bentuk penanaman modal dalam negeri.

Rahman, Soelistyo dan Hadi (2016) melakukan penelitian untuk menguji pengaruh investasi, pengeluaran pemerintah, dan penduduk yang bekerja terhadap PDRB di Banten dan memperoleh hasil bahwa penanaman modal dalam negeri berpengaruh terhadap pertumbuhan ekonomi di Provinsi Banten. Penelitian tersebut sama dengan hasil penelitian yang dilakukan oleh Khairunnisa, Sulistyo dan Kusuma (2018) dan Hapsari dan Prakoso (2016), menguji pengaruh penanaman modal dalam negeri terhadap pertumbuhan ekonomi di Kabupaten/ Kota di Provinsi Kalimantan Selatan. Diperoleh hasil bahwa PMDN berpengaruh terhadap pertumbuhan ekonomi di Kalimantan Selatan.

\section{$\mathbf{H}_{\mathbf{a}}=$ Penanaman Modal Dalam Negeri berpengaruh terhadap pertumbuhan ekonomi}

\section{METODE}

Penelitian ini merupakan penelitian kuantitatif dengan pendekatan deskriptif. Penelitian deskriptif disini yaitu dengan melakukan pengukuran perbandingan kinerja Badan Penanaman Modal khususnya dalam mengelola penanaman modal asing dan penanaman modal dalam negeri di daerah serta pengaruhnya terhadap pertumbuhan ekonomi dalam kurun waktu 2015-2018. Populasi dalam penelitian ini adalah seluruh Provinsi di Indonesia. Sampel dalam penelitian ini ditentukan dengan metode purposive sampling sesuai dengan tujuan penelitian, sehingga yang menjadi sampel penelitian ini adalah 34 Badan Penanaman Modal di setiap Provinsi di Indonesia. Data dalam penelitian ini merupakan data sekunder berupa data target dan realisasi penanaman modal 2015-2018 yang bersumber dari BKPM dan data PDRB 2015-2018 berdasar harga konstan yang bersumber dari BPS. Metode pengumpulan data dalam penelitian ini adalah metode dokumentasi, yaitu dilakukan melalui pencatatan data yang diperlukan dan mengakses website yang menyediakan data dimaksud. Adapun variabel dalam penelitian ini adalah sebagai berikut: 
1) Perbandingan Kinerja Badan Penanaman Modal, diukur dengan menggunakan variabel rata-rata jumlah penanaman modal, rata-rata pertumbuhan penanaman modal dan rasio capaian target penanaman modal

2) Pengaruh Penanaman Modal terhadap Pertumbuhan Ekonomi, variabel bebas (penanaman modal asing dan penanaman modal dalam negeri) dan variabel terikat (pertumbuhan ekonomi)

Teknik analisis data yang digunakan dalam penelitian ini adalah sebagai berikut:

1) Rata-rata jumlah penanaman modal diukur dengan membandingkan rata-rata realisasi penanaman modal asing dan dalam negeri selama kurun waktu 20152018

2) Rata-rata perumbuhan penanaman modal diukur dengan menggunakan rasio CAGR (Compound Annual Growth Rate). CAGR adalah tingkat pertumbuhan tahunan suatu investasi dalam periode tertentu (Guinan, 2010) Adapun formula yang digunakan untuk mengukur rasio CAGR adalah sebagai berikut:

a) Pertumbuhan PMA

CAGR $=\frac{\text { PMA tahun akhir }}{\text { PMA tahun awal }} \frac{1}{\text { jumlahtahun }}-1$

b) Pertumbuhan PMDN

$$
\text { CAGR }=\frac{\text { PMA tahun akhir }}{\text { PMA tahun awal }} \frac{1}{\text { jumlah tahun }}-1
$$

3) Capaian target penanaman modal. Mahmudi (2010), mengatakan rasio yang dapat digunakan untuk mengukur tingkat capaian realisasi terhadap target adalah rasio efektivitas. Adapun formula untuk menghitung rasio efektivitas adalah sebagai berikut:

Efektifitas $=\frac{\text { Realisasi Penanaman Modal }}{\text { Target Penanaman Modal }} \times 100 \%$

Adapun kriteria efektivitas menurut Mahmudi (2010), yaitu:

Tabel 1. Kriteria Efektivitas

\begin{tabular}{lll}
\hline No & Nilai & Kategori \\
1 & $<75 \%$ & Sangat Kurang \\
2 & $75-89 \%$ & Kurang Efektif \\
3 & $90-99 \%$ & Cukup Efektif \\
4 & $100 \%$ & Efektif \\
5 & $>100 \%$ & Sangat Efektif \\
\hline
\end{tabular}

Sumber: Mahmudi (2010)

4) Pengaruh Penanaman Modal Asing dan Penanaman Modal dalam Negeri terhadap Pertumbuhan Ekonomi. Model analisis yang digunakan adalah regresi data panel.

\section{HASIL DAN PEMBAHASAN}

Rata-rata Jumlah Penanaman Modal

Tabel 2. Perkembangan Realisasi Penanaman Modal Asing (Triliun Rupiah)

\begin{tabular}{clrrrrr}
\hline No & \multicolumn{1}{c}{ Provinsi } & 2015 & 2016 & 2017 & 2018 & Rata-rata \\
\hline 1 & Jawa Barat & 71,77 & 74,94 & 68,7 & 105,85 & 80,32 \\
2 & DKI Jakarta & 45,29 & 46,54 & 61,3 & 65,09 & 54,55 \\
3 & Banten & 31,80 & 39,87 & 40,7 & 37,89 & 37,57 \\
4 & Jawa Timur & 32,41 & 26,60 & 20,9 & 17,87 & 24,45 \\
5 & Jawa Tengah & 10,59 & 14,15 & 31,7 & 31,79 & 22,06 \\
$\ldots$ & & & & & & \\
30 & Bangka Belitung & 1,08 & 0,72 & 2 & 0,62 & 1,10 \\
31 & Aceh & 0,31 & 1,84 & 0,3 & 0,95 & 0,85 \\
32 & DI Yogyakarta & 1,14 & 0,30 & 0,5 & 1,09 & 0,76 \\
33 & Gorontalo & 0,11 & 0,18 & 0,5 & 0,55 & 0,33 \\
34 & Sulawesi Barat & 0,004 & 0,29 & 0,1 & 0,33 & 0,18 \\
\hline
\end{tabular}

Sumber: NSWI BKPM, 2020 (data diolah)

Dari Tabel 2 diatas dapat dilihat rata-rata realisasi penanaman modal asing pada setiap provinsi selama kurun waktu 2015-2018. Provinsi Jawa Barat merupakan daerah dengan kinerja terbaik dibandingkan 33 provinsi di Indonesia lainnnya, dengan jumlah rata-rata realisasi penanaman modal asing sebesar $\mathrm{Rp}$ 80,32 Triliun. Provinsi terbaik kedua adalah DKI Jakarta dengan ratarata jumlah realisasi sebesar Rp. 54,55 Triliun.

Provinsi dengan realisasi penanaman asing terendah adalah Provinsi Sulawesi Barat dengan rata-rata jumlah realisasi sebesar Rp 180 Milyar. Provinsi dengan realisasi penanaman modal asing terendah kedua adalah
Gorontalo dengan rata-rata jumlah realisasi sebesar Rp. 330 Milyar. Jika melihat 5 (lima) daerah terbaik ditinjau dari rata-rata jumlah investasi asing di Indonesia masih ditempati oleh Provinsi yang berada di Pulau Jawa, tidak satupun Provinsi di luar Pulau Jawa yang memiliki realisasi investasi asing terbaik. Dengan demikian Provinsi di Pulau Jawa masih menjadi favorit bagi investor asing dalam berinvestasi. Selain investasi asing, investasi dalam negeri juga menjadi salah satu sumber pendanaan oleh Pemerintah Daerah di Indonesia, dibalik kekurangannya dana APBD untuk melakukan pembangunan. 
Fajri Ardiansyah et al, Analisis Perbandingan Kinerja Badan Penanaman Modal serta Pengaruh PMA dan PMDN terhadap Pertumbuhan Ekonomi di Indonesia

Tabel 3. Perkembangan Penanaman Modal dalam Negeri (Triliun Rupiah)

\begin{tabular}{clrrrr}
\hline \multicolumn{1}{c}{ Provinsi } & 2015 & 2016 & 2017 & 2018 & Rata-rata \\
\hline 1 & Jawa Timur & 35,49 & 46,31 & 45,00 & 33,33 \\
2 & Jawa Barat & 26,23 & 30,33 & 38,40 & 42,28 \\
3 & DKI Jakarta & 15,51 & 12,20 & 47,30 & 49,10 \\
4 & Jawa Tengah & 15,41 & 24,03 & 19,90 & 27,47 \\
5 & Banten & 10,70 & 12,43 & 15,10 & 18,64 \\
$\ldots$ & & & & & \\
30 & Bali & 1,24 & 0,48 & 0,60 & 1,03 \\
31 & Maluku Utara & 0,05 & 0,01 & 1,10 & 2,28 \\
32 & Papua & 0,14 & 0,22 & 1,20 & 0,10 \\
33 & Maluku & 0,00 & 0,01 & 0,10 & 0,07 \\
34 & Papua Barat & 0,06 & 0,01 & 0,10 & 0,01 \\
\hline
\end{tabular}

Sumber: NSWI BKPM, 2020 (data diolah)

Dari Tabel 3 diatas dapat dilihat rata-rata realisasi penanaman modal dalam negeri di tiap provinsi di Indonesia selama 2015-2018 yang menunjukan Provinsi Jawa Timur merupakan daerah dengan kinerja terbaik dibandingkan provinsi lainnya di Indonesia, dengan jumlah rata-rata realisasi penanaman modal dalam negeri sebesar Rp 40,03 Triliun. Provinsi terbaik kedua adalah Jawa Barat dengan rata-rata jumlah realisasi sebesar Rp. 34,31 Triliun.

Provinsi dengan realisasi penanaman modal dalam negeri terendah adalah Provinsi Papua Barat dibandingkan dengan 33 Provinsi lainnya di Indonesia dengan rata-rata jumlah realisasi sebesar Rp 60 Milyar. Provinsi dengan realisasi penanaman modal dalam negeri terendah kedua adalah Maluku dengan rata-rata jumlah realisasi sebesar Rp. 280 Milyar.

Jika dilihat dari komposisi Provinsi dengan realisasi penanaman modal dalam negeri terbaik dan terendah, maka Provinsi yang berada di Pulau Jawa masih mendominasi dengan jumlah realisasi investasi dalam negerinya. Lima daerah dengan realisasi penanaman modal dalam negeri tertinggi merupakan provinsi yang ada di Pulau Jawa, sedangkan lima daerah dengan nilai realisasi penanaman modal dalam negeri terendah semuanya merupakan provinsi yang berada di luar Pulau Jawa.

\section{Pertumbuhan Rata-rata Penanaman Modal Asing}

Tabel 4. Pertumbuhan Rata-rata Penanaman Modal Asing

\begin{tabular}{llrrrrr}
\hline & No Provinsi & 2015 & 2016 & 2017 & 2018 & Pertumbuhan Rata-rata (\%) \\
\hline 1 & Sulawesi Barat & 0,004 & 0,29 & 0,1 & 0,33 & 342,98 \\
2 & Bengkulu & 0,25 & 0,76 & 1,9 & 1,83 & 95,19 \\
3 & Gorontalo & 0,11 & 0,18 & 0,5 & 0,55 & 73,29 \\
4 & Sulawesi Tenggara & 1,78 & 5,15 & 9,2 & 9,02 & 71,62 \\
5 & Sulawesi Utara & 1,13 & 5,24 & 6,5 & 3,96 & \\
$\ldots$ & & & & & & \\
30 & Nusa Tenggara Barat & 8,75 & 6,01 & 1,8 & 3,37 & \\
31 & Kalimantan Utara & 2,88 & 2,20 & 2 & 0,9 & $-27,25$ \\
32 & Kalimantan Timur & 29,79 & 15,60 & 17,1 & 7,87 & $-32,13$ \\
33 & Kalimantan Selatan & 12,04 & 3,42 & 3,2 & 1,73 & $-47,83$ \\
34 & Maluku & 1,00 & 1,41 & 2,8 & 0,11 & $-52,09$ \\
\hline
\end{tabular}

Sumber: NSWI BKPM, 2020 (data diolah)

Dari Tabel 4 diatas dapat dilihat rata-rata pertumbuhan penanaman modal asing menggunakan rasio CAGR. Provinsi Sulawesi Barat adalah daerah dengan kinerja terbaik dibandingkan dengan 33 provinsi lainnya di Indonesia dengan pertumbuhan rata-rata sebesar 342,98\%. Provinsi Bengkulu merupakan daerah terbaik kedua dengan pertumbuhan rata-rata tiap tahun adalah $95,19 \%$.
Provinsi dengan tingkat pertumbuhan rata-rata terendah dalam kurun waktu 2015-2018 adalah Maluku dengan nilai pertumbuhan rata-rata sebesar $-52,09 \%$. Provinsi Kalimantan Selatan merupakan daerah dengan kinerja terendah kedua dibandingkan dengan Provinsi lainnya dengan nilai pertumbuhan rata-rata sebesar $47,62 \%$. 
Fajri Ardiansyah et al, Analisis Perbandingan Kinerja Badan Penanaman Modal serta Pengaruh PMA dan PMDN terhadap Pertumbuhan Ekonomi di Indonesia

Tabel 5. Pertumbuhan Rata-rata Penanaman Modal dalam Negeri

\begin{tabular}{clrrrrr}
\hline No & \multicolumn{1}{c}{ Provinsi } & 2015 & 2016 & 2017 & 2018 & Pertumbuhan Rata-rata (\%) \\
\hline 1 & Maluku & 0,01 & 0,01 & 0,1 & 1,01 & 365,70 \\
2 & Maluku Utara & 0,05 & 0,01 & 1,1 & 2,28 & 261,58 \\
3 & Gorontalo & 0,09 & 2,20 & 0,9 & 2,67 & 204,78 \\
4 & DI Yogyakarta & 0,36 & 0,92 & 0,3 & 6,13 & 156,71 \\
5 & Sulawesi Utara & 0,27 & 5,07 & 1,5 & 4,32 & \\
$\ldots$ & & & & & \\
30 & Sulawesi Tenggara & 2,02 & 1,79 & 3,1 & 1,6 & $-7,41$ \\
31 & Papua Barat & 0,06 & 0,01 & 0,1 & 0,05 & $-1,63$ \\
32 & Papua & 0,14 & 0,22 & 1,2 & 0,1 & $-29,13$ \\
33 & Sulawesi Selatan & 9,22 & 3,33 & 2 & 3,28 & $-38,61$ \\
34 & Aceh & 4,19 & 2,46 & 0,8 & 0,97 & \\
\hline
\end{tabular}

Sumber: NSWI BKPM, 2020 (data diolah)

Dari Tabel 5 diatas dapat diketahui rata-rata pertumbuhan penanaman modal dalam negeri selama 2015-2018 dengan menggunakan rasio CAGR. Provinsi Maluku adalah daerah dengan kinerja terbaik dibandingkan dengan 33 provinsi lainnya di Indonesia dengan pertumbuhan rata-rata sebesar $365,70 \%$. Provinsi Maluku Utara merupakan daerah terbaik kedua dengan pertumbuhan rata-rata tiap tahun adalah 261,58\%.

Provinsi dengan pertumbuhan rata-rata penanaman modal dalam negeri terendah adalah Aceh dengan dengan nilai $-38,61$. Provinsi Sulawesi Selatan merupakan daerah dengan kinerja terendah kedua dengan nilai pertumbuhan rata-rata sebesar $-29,13 \%$.

Melihat trend penanaman modal dalam negeri yang meningkatkan pada tahun 2018, maka penanaman modal dalam negeri bisa menjadi andalan pemerintah dalam melaksanakan pembangunan ditengah keterbatas APBN dan lesunya ekonomi global.

\section{Capaian Target Penanaman Modal}

Tabel 6. Rasio Capaian Target Penanaman Modal (\%)

\begin{tabular}{clrrrrrr}
\hline No & \multicolumn{1}{c}{ Provinsi } & 2015 & \multicolumn{1}{c}{2016} & \multicolumn{1}{c}{2017} & 2018 & Rata-rata & Kriteria \\
\hline 1 & Sulawesi Utara & 82,35 & 412,40 & 205,13 & 122,85 & 205,68 & Sangat Efektif \\
2 & Lampung & 138,71 & 206,00 & 162,26 & 206,75 & 178,43 & Sangat Efektif \\
3 & DI Yogyakarta & 166,67 & 124,49 & 38,10 & 338,97 & 167,05 & Sangat Efektif \\
4 & Aceh & 500,00 & 66,46 & 20,75 & 28,19 & 153,85 & Sangat Efektif \\
5 & Papua & 83,33 & 74,64 & 407,58 & 41,23 & 151,69 & Sangat Efektif \\
$\ldots$ & & & & & & & \\
30 & Maluku & 100,00 & 154,35 & 46,77 & 15,45 & 79,14 & Kurang Efektif \\
31 & Papua Barat & 73,33 & 145,36 & 5,94 & 44,15 & 67,20 & Sangat Kurang \\
32 & Maluku Utara & 30,59 & 97,10 & 40,20 & 88,37 & 64,06 & Sangat Kurang \\
33 & Kalimantan Selatan & 81,98 & 57,82 & 29,81 & 45,04 & 53,66 & Sangat Kurang \\
34 & Kalimantan Utara & 14,96 & 22,17 & 85,29 & 48,71 & 42,78 & Sangat Kurang \\
\hline
\end{tabular}

Sumber: NSWI BKPM, 2020 (data diolah)

Dari Tabel 6 diatas dapat dilihat rata-rata capaian target penanaman modal dengan menggunakan rasio efektivitas. Provinsi dengan kinerja terbaik jika dilihat dari rasio efektivitas penanaman modal selama 4 tahun adalah Sulawesi Utara dengan rata-rata 205,68\% dengan kriteria "Sangat Efektif". Provinsi Lampung merupakan daerah terbaik kedua dengan rata-rata capaian sebesar $178,43 \%$ dan kriteria "Sangat Efektif".

Sedangkan daerah dengan kinerja capaian realisasi terhadap target penanaman modal terendah adalah Kalimantan Utara dengan nilai capaian sebesar 42,78\% dan kriteria "Sangat Kurang". Nilai capaian sebesar $53,66 \%$ dan kriteria "Sangat Kurang"menjadikan Provinsi Kalimantan Selatan sebagai daerah dengan kinerja penanaman modal terendah kedua.
Meningkatnya nilai capaian realisasi terhadap target penanaman modal di daerah di Indonesia tentu tidak terlepas dari peran pemerintah daerah itu sendiri untuk menarik investasi datang ke daerahnya. Pemerintah Indonesia sadar bahwa untuk meningkatkan iklim investasi harus dengan mengutamakan perbaikan infrastruktur, sehingga saat ini yang menjadi fokus Pemerintah adalah membangun infrastrukur, terutama yang menghubungkan sentra-sentra ekonomi produktif (Sugiarto, 2019).

Pengaruh Penanaman Modal Asing dan Penanaman Modal dalam Negeri terhadap Pertumbuhan Ekonomi F-test 
Fajri Ardiansyah et al, Analisis Perbandingan Kinerja Badan Penanaman Modal serta Pengaruh PMA dan PMDN terhadap Pertumbuhan Ekonomi di Indonesia

\begin{tabular}{|c|c|c|c|c|c|c|}
\hline \multicolumn{7}{|c|}{$\begin{array}{c}\text { Tabel 7. Uji F } \\
\text { ANOVA }^{\mathbf{a}}\end{array}$} \\
\hline \multicolumn{2}{|c|}{ Model } & Sum of Squares & df & Mean Square & $\mathrm{F}$ & Sig. \\
\hline & Regression & 126.699 & 2 & 63.350 & 181.921 & $.000^{\mathrm{b}}$ \\
\hline 1 & Residual & 45.618 & 131 & .348 & & \\
\hline & Total & 172.317 & 133 & & & \\
\hline
\end{tabular}

a. Dependent Variable: Lny

b. Predictors: (Constant), Lnx2, Lnx1

Sumber: Output SPSS (data diolah)

Dari Tabel 7 diatas dapat dilihat bahwa nilai $\mathrm{F}$ hitung adalah 181,921 dengan signifikan 0,00. Sedangkan nilai F tabel adalah sebesar 3,065296. Nilai F hitung $>\mathrm{F}$ tabel dan signifikan $<0,05$, maka $\mathrm{H}_{0}$ ditolak, artinya terdapat pengaruh positif dan signifikan variabel penanaman modal asing dan penanaman modal dalam negeri secara simultan terhadap pertumbuhan ekonomi.

Hasil analisis ini sama dengan hasil penelitian yang dilakukan oleh Rahman dan Hadi (2016), yang diperoleh hasil secara simultan Investasi (PMA dan PMDN), pengeluaran pemerintah, tenaga kerja (Angkatan Kerja yang bekerja) berpengaruh positif dan signifikan terhadap PDRB di Provinsi Banten. Hal ini senada dengan hasil penelitian Rizky dan Agustin (2018), dimana secara simultan PMA, PMDN dan Belanja Modal berpengaruh positif dan signifikan terhadap pertumbuhan ekonomi di Indonesia. Begitu juga dengan penelitian yang dilakukan oleh Khairunnisa, Sulistyo dan Kusuma (2018), dimana Secara simultan, PMA, PMDN dan Pengeluaran pemerintah berpengaruh positif dan signifikan terhadap PDRB di Provinsi Kalimantan Selatan.

$\mathrm{t}-$ test

Tabel 8. Hasil Uji t

Coefficients $^{\mathrm{a}}$

\begin{tabular}{|c|c|c|c|c|c|c|}
\hline \multirow{2}{*}{\multicolumn{2}{|c|}{ Model }} & \multicolumn{2}{|c|}{ Unstandardized Coefficients } & \multirow{2}{*}{$\begin{array}{c}\text { Standardized Coefficients } \\
\text { Beta }\end{array}$} & \multirow[t]{2}{*}{$\mathrm{t}$} & \multirow[t]{2}{*}{ Sig. } \\
\hline & & $\mathrm{B}$ & Std. Error & & & \\
\hline \multirow{3}{*}{1} & (Constant) & 4.118 & .072 & & 57.283 & .000 \\
\hline & Lnx1 & .374 & .037 & .510 & 9.992 & .000 \\
\hline & Lnx2 & .312 & .033 & .489 & 9.593 & .000 \\
\hline
\end{tabular}

a. Dependent Variable: Lny

Sumber: Output SPSS (data diolah)

Dari Tabel 8 diatas dapat dilihat hasil uji t pada variabel penanaman modal asing dan penanaman modal dalam negeri. Nilai t pada variabel penanaman modal asing adalah 9,992 dengan nilai t tabel sebesar 1,978239 dan signifikan 0,00. Dengan demikian nilai $\mathrm{t}$ hitung $>\mathrm{t}$ tabel dan signifikan $<0,00$, maka $\mathrm{H}_{0}$ ditolak. Artinya terdapat pengaruh positif dan signifikan penanaman modal asing terhadap pertumbuhan ekonomi.

Hasil analisis ini sama dengan hasil penelitian Rizky dan Agustin (2018), dimana secara parsial PMA berpengaruh positif dan signifikan terhadap pertumbuhan ekonomi di Indonesia. Hal ini juga senada dengan hasil penelitian Rahman dan Hadi (2016), dimana PMA juga berpengaruh positif terhadap pertumbuhan ekonomi di Provinsi Banten. Demikian juga dengan penelitian yang dilakukan oleh Khairunnisa, Sulistyo dan Kusuma (2018), dimana Secara parsial PMA berpengaruh positif dan signifikan terhadap PDRB di Provinsi Kalimantan Selatan.

Namun hasil penelitian ini bertolak belakang dengan penelitian Hapsari dan Prakoso (2016) yang menyatakan bahwa PMA tidak berpengaruh terhadap pertumbuhan ekonomi. Begitu juga dengan penelitian oleh Asiyan (2013) juga menyatakan bahwa PMA tidak berpengaruh terhadap pertumbuhan ekonomi.
Nilai $\mathrm{t}$ pada variabel penanaman modal dalam negeri adalah 9,593 dengan nilai $t$ tabel sebesar 1,978239 dan signifikan 0,00. Dengan demikian nilai t hitung $>\mathrm{t}$ tabel dan signifikan $<0,00$, maka $\mathrm{H}_{0}$ ditolak. Artinya terdapat pengaruh positif dan signifikan penanaman modal dalam negeri terhadap pertumbuhan ekonomi.

Hasil analisis ini sama dengan hasil penelitian Rahman dan Hadi (2016), dimana PMDN berpengaruh positif terhadap pertumbuhan ekonomi di Provinsi Banten. Hal ini juga senada dengan penelitian dari Rizky dan Agustin (2018), dimana secara parsial PMDN berpengaruh positif dan signifikan terhadap pertumbuhan ekonomi di Indonesia. Begitu juga dengan hasil penelitian yang dilakukan oleh Khairunnisa, Sulistyo dan Kusuma (2018), dimana Secara parsial PMDN berpengaruh positif dan signifikan terhadap PDRB di Provinsi Kalimantan Selatan. Dalam penelitian Hapsari dan Prakoso (2016) juga diperoleh hasil bahwa PMDN berpengaruh positif terhadap pertumbuhan ekonomi

Namun hasil analisis ini bertolak belakang dengan hasil penelitian yang dilakukan oleh Asiyan (2013) yang menyatakan bahwa PMDN tidak berpengaruh terhadap pertumbuhan ekonomi. 
Dari Tabel 8 diatas juga dapat dibuat persamaan regresi pada penelitian ini sebagai berikut:

$$
\begin{aligned}
& Y_{i t}=\alpha+\beta_{1} X_{1 i t}+\beta_{2} X_{2 i t}+e_{i t} \\
& Y_{i t}=4,118+0,374 \operatorname{Ln} X_{1 i t}+0,312 \operatorname{Ln} X_{2 i t}+e_{i t}
\end{aligned}
$$

Dimana persamaan regresi diatas dapat dijelaskan sebagai berikut:

- Konstanta sebesar 4,118, artinya Jika penanaman modal asing (X1) dan penanaman modal dalam negeri (X2) nilainya adalah 0 , maka pertumbuhan ekonomi (Y) adalah 4,118;

- Koefisien regresi X1 sebesar 0,374, artinya jika variabel bebas lainnya nilainya tetap dan penanaman modal asing mengalami kenaikan 1\%, maka pertumbuhan ekonomi akan naik sebesar 0,374;

- Koefisien regresi X2 sebesar 0,312, artinya jika variabel bebas lainnya nilainya tetap dan penanaman modal dalam negeri mengalami kenaikan $1 \%$, maka pertumbuhan ekonomi akan naik sebesar 0,312.

\section{SIMPULAN}

Berdasarkan Rata-rata Jumlah Realisasi Penanaman Modal Asing, dapat disimpulkan bahwa lima daerah dengan kinerja terbaik adalah Provinsi Jawa Barat dengan nilai rata-rata realisasi sebesar Rp. 80,32 Triliun. Selanjutnya pada posisi kedua ada Provinsi DKI Jakarta dan dilanjutkan oleh Provinsi Banten, Jawa Timur dan Jawa Tengah pada urutan ketiga, keempat dan kelima.

Sedangkan dari rata-rata jumlah realisasi penanaman modal dalam negeri, dapat disimpulkan bahwa daerah yang memiliki kinerja terbaik adalah Provinsi Jawa Timur dengan rata-rata realisasi penanaman modal dalam negeri sebesar Rp. 40,03 Triliun. Sedangkan pada peringkat kedua adalah Provinsi Jawa Barat. Dilanjutkan dengan Provinsi DKI Jakarta, Jawa Tengah dan Banten pada peringkat ketiga, keempat dan kelima.

Pertumbuhan rata-rata per tahun Penanaman Modal Asing dengan menggunakan rasio CAGR disimpulkan bahwa maka provinsi yang memiliki kinerja terbaik adalah Sulawesi Barat. Urutan selanjutnya ada Provinsi Bengkulu, Gorontalo, Sulawesi Tenggara dan Sulawesi Utara.

Sedangkan pertumbuhan rata-rata per tahun Penanaman Modal dalam Negeri dengan menggunakan rasio CAGR, maka provinsi yang memiliki kinerja terbaik adalah Maluku. Urutan selanjutnya ada Provinsi Maluku Utara, Gorontalo, DI Yogyakarta dan Sulawesi Utara.

Dari hasil rasio Capaian Realisasi terhadap Target Penanaman Modal, dapat disimpulkan daerah yang memiliki kinerja terbaik adalah Sulawesi Utara (Sangat Efektif), Lampung (Sangat Efektif), DI Yogyakarta
(Sangat Efektif), Aceh (Sangat Efektif) dan Papua (Sangat Efektif).

Berdasarkan uji F, diperoleh hasil $\mathrm{F}$ hitung sebesar 383,312 dengan signifikan 0,00. Sedangkan nilai $F$ tabel adalah sebesar 3,0642338. Nilai F hitung $>F$ tabel dan signifikan $<0,05$, maka $\mathrm{H}_{0}$ ditolak, artinya terdapat pengaruh positif dan signifikan variabel penanaman modal asing dan penanaman modal dalam negeri secara simultan terhadap pertumbuhan ekonomi.

Berdasarkan uji t pada variabel penanaman modal asing, diperoleh hasil t hitung sebesar 5,378 dengan nilai $\mathrm{t}$ tabel sebesar 1,97796126 dan signifikan 0,00. Dengan demikian nilai $\mathrm{t}$ hitung $>\mathrm{t}$ tabel dan signifikan $<0,00$, maka $\mathrm{H}_{0}$ ditolak. Artinya terdapat pengaruh positif dan signifikan penanaman modal asing terhadap pertumbuhan ekonomi.

Sedangkan hasil uji t pada variabel penanaman modal dalam negeri, diperoleh hasil t hitung sebesar 14,079 dengan nilai t tabel sebesar 1,97796126 dan signifikan 0,00 . Dengan demikian nilai $\mathrm{t}$ hitung $>\mathrm{t}$ tabel dan signifikan $<0,00$, maka $\mathrm{H}_{0}$ ditolak. Artinya terdapat pengaruh positif dan signifikan penanaman modal dalam negeri terhadap pertumbuhan ekonomi.

\section{DAFTAR PUSTAKA}

Adipuryanti, Ni Luh Putu Yuni dan I Ketut Sudibia. 2015. "Analisis Pengaruh Jumlah Penduduk yang Bekerja dan Investasi Terhadap Ketimpangan Distribusi Pendapatan Melalui Pertumbuhan Ekonomi Kabupaten/ Kota di Bali”. Piramida Jurnal Kependudukan dan Pengembangan Sumber Daya Manusia.Vol Xi No.1: 20-28

Agus Tri Basuki and Prawoto, Nano. 2017. Analisis Regresi Dalam Penelitian Ekonomi \& Bisnis : Dilengkapi Aplikasi SPSS \& EVIEWS. Depok: PT Rajagrafindo Persada.

Ambasari, Indah dan Purnomo, Didit. 2005. "Studi tentang Penanaman Modal Asing di Indonesia". Jurnal Ekonomi dan Pembangunan, Volume 6, No.1, Hal. 26-47.

Aminda, Renea Shinta dan Rinda, Rachmatulaily Tinakartika. 2019. "Analisis Penanaman Modal Asing dan Penanaman Modal dalam Negeri dan Pengaruhnya terhadap Pertumbuhan Ekonomi (Tahun 2010-2018)". Proceeding Seminar Nasional dan Call for Papers 2019. Universitas Stikubank Madic ISSN: 2443-2601.

Asiyan, Sri. 2013. "Pengaruh Penanaman Modal Dalam Negeri, Penanaman Modal Asing, dan Ekspor terhadap Pertumbuhan Ekonomi Jawa Timur". Jurnal Pendidikan Ekonomi UNESA

Asri, Nur. 2005. "Pengaruh Pengeluaran Pemerintah Terhadap Pertumbuhan Ekonomi dan Distribusi Pendapatan (Kajian Antar Propinsi di Indonesia Periode 1994-2003)". Pascasarjana Universitas Andalas Padang 
Fajri Ardiansyah et al, Analisis Perbandingan Kinerja Badan Penanaman Modal serta Pengaruh PMA dan PMDN terhadap Pertumbuhan Ekonomi di Indonesia

Badan Pusat Statistik. 2016. Statistik Indonesia 2016. Jakarta: Badan Pusat Statistik

Badan Pusat Statistik. 2017. Statistik Indonesia 2017. Jakarta: Badan Pusat Statistik

Badan Pusat Statistik. 2018. Statistik Indonesia 2018. Jakarta: Badan Pusat Statistik

Badan Pusat Statistik. 2019. Statistik Indonesia 2019. Jakarta: Badan Pusat Statistik

BKPM. 2015. Peraturan Kepala BKPM Nomor 9 Tahun 2015 tentang "Penyelenggaraan Pelayanan Terpadu Satu Pintu Pusat di BKPM"

Firdaus, Dony Waluya dan Widyasastrena, Dimas. 2016. Kajian Pertumbuhan Minat dan Realisasi Investasi Penanaman Modal Asing (PMA) dan Penanaman Modal Dalam Negeri (PMDN) Jawa Barat (Lokasi dan Sektor Usaha. Jurnal Riset Akuntansi Vol VIII No.2 Oktober 2016.

Guinan, Jack.(2010). INVESTOPEDIA : Cara Mudah Memahami Istilah Investasi. Cetakan I. Jakarta: Hikmah

Ghozali, Imam. 2006. Aplikasi Analisis Multivariate dengan Program SPSS Cetakan IV. Semarang: Badan Penerbit Univesitas Diponegoro.

Ghozali, Imam. 2013. Aplikasi Analisis Multivariate dengan Program SPSS. Semarang: Badan Penerbit Univesitas Diponegoro.

Hapsari, Dian Rahma dan Prakoso, Imam. 2016. "Penanaman Modal dan Pertumbuhan Ekonomi Tingkat Provinsi di Indonesia". Jurnal Ekonomi dan Bisnis Vol 19 No 2. Universitas Kristen Satya Wacana

Jones, Gareth R., 1993.Organizational Theory: Textand Cases, Addison Wesley Publishing Company

Khairunnisa, Aris Soelistyo, dan Hendra Kusuma. 2017. "Pengaruh Penanaman Modal Asing dan Domestik Serta Pengeluaran Pemerintah Terhadap Produk Domestik Bruto di Kabupaten/ Kota Provinsi Kalimantan Selatan tahun 20112015”. Jurnal Ilmu Ekonomi Vol 1 Jilid 4/ Tahun 2017. Universitas Muhammadiyah Malang

Kristiyanti, Mariana. 2012. Peran Indikator Kinerja dalam Mengukur Kinerja Manajemen. Majalah Ilmiah Informatika Vol 3 No 3, Sept 2012.

Mahmudi. 2010. Manajemen Keuangan Daerah. Jakarta: Penerbit Erlangga

Mahsun, Mohamad. (2009). Pengukuran Kinerja Sektor Publik (3th ed). Yogyakarta: BPFE

Mailindra, Wiyan. 2016. "Pengaruh Keragaman Belanja Terhadap Ketimpangan Pendapatan antar Daerah di Provinsi Jambi". Jurnal of Economics and Business Vol.1 No. 1 September 2017

Nurmilah, Risma. 2016. "Pengaruh Penanaman Modal Asing dan Human Capital Terhadap Pertumbuhan Ekonomi (studi kasus 33 Provinsi)". Jurnal Ilmiah Ilmu Ekonomi Vol 5 Edisi 9, Oktober 2016 Institut Pertanian Bogor
Presiden RI. 2014. Peraturan Presiden Nomor 97 Tahun 2014 tentang "Penyelenggaraan Pelayanan Terpadu Satu Pintu Pusat di Badan Koordinasi Penanaman Modal"

Presiden RI. 2015. Instruksi Presiden Nomor 4 Tahun 2015 tentang "Penyelenggaraan Pelayanan Terpadu Satu Pintu Pusat di Badan Koordinasi Penanaman Modal"

Rahman, Jazuli Ahmad, Aris Soelistyo dan Syamsul Hadi. 2016. "Pengaruh Investasi, Pengeluaran Pemerintah dan Tenaga Kerja Terhadap PDRB Kabupaten/ Kota di Provinsi Banten Tahun 20102014”. Jurnal Ekonomi Pembangunan Vol. 14, No 02 Desember 2016. Fakultas Ekonomi dan Bisnis Universitas Muhammadiyah Malang

Republik Indonesia. Peraturan Pemerintah Nomor 24 Tahun 2019. tentang "Pemberian Insentif dan Kemudah Investasi di Daerah". Lembaran Negara Republik Indonesia

Republik Indonesia. Undang-Undang Nomor 23 Tahun 2014. tentang "Pemerintahan Daerah". Lembaran Negara Republik Indonesia

Rizky, Reza Lainatul, Grisvia Agustin, Imam Mukhlis. 2016. "Pengaruh Penanaman Modal Asing, Penanaman Modal dalam Negeri dan Belanja Modal Terhadap Pertumbuhan Ekonomi Provinsi di Indonesia". JESP-Vol 8 No 1 Maret 2016. Fakultas Ekonomi Universitas Negeri Malang

Sabir. 2015. "Pengaruh Alokasi Belanja Modal Terhadap Pertumbuhan Ekonomi, Ketimpangan Pendapatan, Penyerapan Tenaga Kerja dan Kesejahteraan Masyarakat Kabupaten/Kota Di Provinsi Sulawesi Selatan Tahun 2008-2013)". Disertasi Program Doktor Ilmu Ekonomi Universitas Brawijaya Malang

Sekaran, Uma. 2007. "Metode Penelitian Bisnis 2 Edisi 4". Jakarta: Salemba Empat . 2007. "Metode Penelitian Bisnis 1 Edisi 4". Jakarta: Salemba Empat

Sitinjak, Robudi Musa. 2011. "Analisa Faktor-Faktor yang Mempengaruhi Penanaman Modal Asing Langsung di Indonesia". Tesis Fakultas Ekonomi Program Studi Magister Perencanaan dan Kebijakan Publik Universitas Indonesia. Jakarta

Sugiarto, Eddy Cahyono. 2006. "Investasi dan Indonesia Maju”. Artikel dalam www.setneg.go.id.

Sukirno, Sadono. 2004. "Makro Ekonomi Teori Pengantar Edisi Ketiga". Jakarta: Penerbit PT Raja Grafindo Persada.

Sulle, Andrew. 2014. The Use of Performance Measurement Information in the Tanzanian Public Sektor: The Case of National Housing Corporation. International Joutnal of Management Sciences and Business Research , 2014 ISSN (2226-8235) Vol-3 Issue 7. 
Fajri Ardiansyah et al, Analisis Perbandingan Kinerja Badan Penanaman Modal serta Pengaruh PMA dan PMDN terhadap Pertumbuhan Ekonomi di Indonesia

Syafrizal. 2008. "Ekonomi Regional Teori dan Aplikasi". Cetakan Pertama, Padang: Baduose

Tambunan, Tulus. 2006. "Iklim Investasi di Indonesia: Masalah, Tantangan dan Potensi". Artikel dalam www.kadin-indonesia.or.id

Todaro, M.P. 2000. "Pembangunan Ekonomi Dunia” Ke Tiga. Edisi Ketujuh. Jakarta: Erlangga.

Todaro, Michael and Smith, Stephen C. 2003. "Economic Development". Pearson Education. Limited.

Wahyuni, I Gusti Ayu Putri, Made Sukarsa dan Nyoman Yuliarmi. 2014. "Pengaruh Pengeluaran Pemerintah dan Investasi terhadap Pertumbuhan Ekonomi dan Kesejangan Pendapatan di Kabupaten/ Kota di Provinsi Bali ”. EJurnal Ekonomi dan Bisni Universitas Udayana 3.8 (2014):458-477

Zaenuddin, Muhammad. 2009. "Analisis Faktor yang Mempengaruhi Investasi PMA di Batam”. JEJAK, Volume 2, Nomor 2, September 2009. 